\title{
Gary Victor, À l'angle des rues parallèles
}

\section{Paola Ghinelli}

\section{(2) OpenEdition}

\section{Journals}

\section{Édition électronique}

URL : http://journals.openedition.org/studifrancesi/35361

DOI : 10.4000/studifrancesi.35361

ISSN : 2427-5856

\section{Éditeur}

Rosenberg \& Sellier

\section{Édition imprimée}

Date de publication : 1 novembre 2005

Pagination : 463-464

ISSN : 0039-2944

\section{Référence électronique}

Paola Ghinelli, « Gary Victor, À l'angle des rues parallèles », Studi Francesi [En ligne], 146 (XLIX | II) | 2005,

mis en ligne le 30 novembre 2015, consulté le 18 avril 2021. URL : http://journals.openedition.org/ studifrancesi/35361 ; DOI : https://doi.org/10.4000/studifrancesi.35361

\section{Ce document a été généré automatiquement le 18 avril 2021.}

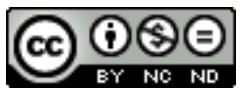

Studi Francesi è distribuita con Licenza Creative Commons Attribuzione - Non commerciale - Non opere derivate 4.0 Internazionale. 


\title{
Gary Victor, À l'angle des rues parallèles
}

\author{
Paola Ghinelli
}

\section{RÉFÉRENCE}

GARY VICTOR, À l'angle des rues parallèles, Châteauneuf-le-Rouge, Vents d'ailleurs, 2003, pp. 191.

1 Gary Victor, un des romanciers haïtiens les plus lus en Haïti, a connu le succès européen en 2002, grâce à la publication de son œuvre en France. En réalité, à partir des années 1980 il a écrit et publié dans son île natale les romans et les nouvelles qui sont maintenant édités pour le lectorat occidental. Ainsi, La piste des sortilèges, le roman qui a attiré l'attention de la critique française en 2002, avait été publié par les éditions Deschamps en 1996, tandis qu'À l'angle des rues parallèles était sorti, toujours en Haïti, en l'an 2000. Ces données n'ont pas uniquement une importance d'ordre sociologique, car les mécanismes de diffusion et les modalités de réception peuvent avoir une influence certaine sur la créativité de l'auteur. En outre, il est important de connaître le contexte de la première publication d'une œuvre comme celle dont nous parlons qui est consacrée à la dérive politique et morale d'un pays. La version que nous proposent les Vents d'ailleurs est identique à la précédente, à ceci près qu'elle est complétée par un glossaire.

2 Le protagoniste de ce récit, qui en est aussi le narrateur, exaspéré par une situation sentimentale difficile qu'il attribue à des programmes d'ajustement structurel, se fraie un chemin dans la société haïtienne contemporaine par l'emploi répété de la violence. Son objectif déclaré est celui de tuer le ministre qu'il considère responsable de son malheur privé. Cette histoire se déroule pourtant dans un contexte surréaliste où, petit à petit, les miroirs deviennent aveugles, l'écriture s'inverse, les statues s'animent, et la population s'abandonne à une panique apocalyptique. L'efficacité métaphorique de ce récit est remarquable, d'autant plus que le protagoniste, concentré sur son plan 
meurtrier, ne se laisse pas distraire par la terreur ambiante. Le lecteur est donc forcé de s'interroger sur les raisons des événements absurdes qui se multiplient, jusqu'à ce que le sens de cette apocalypse s'impose. Il s'agit en effet d'un châtiment qui tombe sur un peuple immobile qui ne va "plus à la rencontre de l'autre. Immobiles, nous trompions toujours l'autre (...) afin que nous puissions le prendre au piège de notre immobilité. Mais comme le mouvement est une nécessité immuable, ce lieu avait commencé à se désagréger. Le temps ne pouvait vivre que dans la vitalité de l'esprit, tout comme l'arbre vit du soleil. Alors, il avait choisi de se saborder pour engloutir dans le néant aussi bien les acteurs que la scène». La situation est donc sans espoir, mais la conclusion est ambiguë, car à l'angle des rues parallèles tout est possible. 